\title{
Party System Nationalisation and Non-uniform Vote Switching. Evidence from the Czech Republic*
}

\author{
PAT LYONS and LUKÁŠ LINEK** \\ Institute of Sociology, Academy of Sciences of the Czech Republic, Prague
}

\begin{abstract}
National rather than regional party systems are the norm in most democratic states. This has been interpreted as meaning that most voters view inter-party competition in the same way. With a high level of party system nationalisation the relative proportion of electoral support attracted by parties across all constituencies tends to be very similar although the absolute level of party support changes across elections. Sociological and institutional explanations have been used to account for party system nationalisation. Both of these explanations have generally made causal inferences using aggregate data. The link between party system nationalisation and the individual voter has not been examined in the same detail. Here this link is explored using an ecological inference analysis of vote switching. This research, using the Czech Republic as a case study, shows that the presence of high party system nationalisation evident across a pair of elections may be associated with nonuniform electoral swings. These results demonstrate that evidence of party system nationalisation should not be taken to mean that all voters view electoral choices in the same way.
\end{abstract}

Keywords: party system nationalisation, vote switching, ecological inference, Czech Republic

Sociologický časopis/Czech Sociological Review, 2010, Vol. 46, No. 3: 375-399

The question of why some states have a relatively small set of parties that compete across the entire territory of the state instead of having many local parties with a narrow geographical focus is an important topic. This is because in most democratic states 'national' rather than 'local' party systems are currently the norm. It has been suggested that this implies that voters view party politics and

\footnotetext{
* An earlier version of this paper was presented at ECPR Workshop Panel No. 1 on 'The Nationalisation of Party Systems in Central and Eastern Europe', Rennes, France, 11-16 April 2007. In undertaking this research the authors gratefully acknowledge funding from the Czech Grant Agency (Grant No. 407/07/1395).

** Direct all correspondence to: Pat Lyons, Department of Political Sociology, Institute of Sociology, Academy of Sciences of the Czech Republic, Jilská 1, 11000 Prague 1, Czech Republic, e-mail: Pat.Lyons@soc.cas.cz; Lukáš Linek, Department of Political Sociology, Institute of Sociology, Academy of Sciences of the Czech Republic, Jilská 1, 11000 Prague 1, Czech Republic, e-mail: Lukas.Linek@soc.cas.cz.
}

(C) Sociologický ústav AV ČR, v.v.i., Praha 2010 
electoral competition in the same way, where support for local parties is the exception rather than the rule. The emergence of one national rather than many local party systems in a state has been explained using sociological and institutional theories.

Within the sociological perspective, Lipset and Rokkan [1967] emphasised the importance of social cleavages in the development of party competition and electoral behaviour in Western Europe. Caramani [2004], employing a similar socio-structural approach, has mapped out the emergence of party system nationalisation using a unique constituency level dataset that extends across many West European states following the emergence of competitive general elections with progressive extensions of the franchise. In contrast, the institutional explanation of party system nationalisation explores how electoral rules give incentives to parties and voters to coordinate [Cox 1997, 1999]. Voters and parties are seen to coordinate their party choices at the district and national levels [Chhibber and Kollman 1998, 2004; Samuels 2000; Hicken 2009].

Of course, the sociological and institutional explanations of party system nationalisation are not mutually exclusive. For example, social cleavages may reduce the incentives for parties and voters to coordinate at the constituency and national levels [Ferree 2010]. To date tests of the sociological and institutional explanations of party system nationalisation have been based on (1) analyses of aggregate (constituency) level data, and (2) examinations of single elections.

In this article we will relax these two assumptions. There will be an exploration of how individual voters' behaviour, derived from an ecological inference analysis of aggregated election results, varies across a pair of elections that are known to exhibit high levels of party system nationalisation. The analyses presented demonstrate that high levels of party system nationalisation can be associated with non-uniform electoral swings arising from distinct regional vote switching patterns. Here the results of sub-constituency electoral data analyses will be presented. The motivation for such regional differences is presented using some insights from an influential vote switching model, namely, the Second Order Election Thesis. This model contends that voter turnout will be lower in 'less important' contests such as European Parliament elections because such 'second-order' contests do not result in a government. Moreover, in comparison to the most recent general election (larger) governing parties will lose support and (smaller) opposition parties will gain votes. The evidence presented in this article suggests that Caramani's [2004: 39-40] contention that uniform electoral swings are associated with nationalisation and non-uniform swings stem from local factors is not always true.

This article is organised as follows. In the first section, there is an overview of the party system nationalisation literature with a special emphasis on measurement. In section two, the evidence illustrating party system nationalisation in the Czech Republic is presented. Thereafter, in the third section there is an explanation of how the analysis of party system nationalisation may be profitably 
linked to the study of vote switching. In the fourth section there is an explanation of how the latent structure approach to ecological inference may be used to explore the link between party system nationalisation and the individual voter. The penultimate section presents the main results from the ecological inference analyses, and this is followed by some concluding remarks.

\section{Party system nationalisation: level of analysis}

The emergence of national party systems has often been associated with key features of the process of democratisation such as extension of the franchise [Cox 1997; Chhibber and Kollman 1998, 2004; Caramani 2004: 2, 7, 290, 299; Rokkan 1970: 277; Hicken 2009]. This process is generally long-term in nature and encompasses a wide range of other phenomena; and is characterised by a multiplicity of origins and consequences. In order to make the study of party system nationalisation tractable, research has most often focused on electoral outcomes derived from an analysis of constituency results. ${ }^{1}$

Even within this narrower conceptualisation there are identifiable streams of work. American scholars have tended to adopt an institutional orientation and have investigated the national and local components of voter turnout and party support across different types of elections and electoral systems [Morgernstern and Swindle 2005; Alemán and Kellam 2008]. Within Europe the emphasis has had a more macro-sociological and historical hue. Here the focus has been on explaining the degree to which local or regional voting is the product of value divisions within society combined with institutional differences [Caramani 2004; Tiemann 2005; Cox 1997; Chhibber and Kollman 2004; Ferree 2010].

Without getting into the details of the party system nationalisation literature one may reasonably argue that the most important feature of this field of research is that the level of analysis is almost always aggregate: there are few, if any, individual level explanations of political system nationalisation. This characteristic stems from the practical fact that the electoral data used to examine party system nationalisation occur at the constituency level; and such data are the only consistent source of voting information across time. ${ }^{2}$ The type of expla-

\footnotetext{
1 There is some debate about the merits of considering party system nationalisation a 'process' or an 'outcome.' On the one hand, Caramani's [2004] work emphasises the process of political change since the 19th century, and makes frequent reference to Lipset and Rokkan [1967] which has a strong historical (process based) approach. On the other hand, the various measures of party system nationalisation are calculated using electoral outcomes [Bochsler 2010]. In sum, definition of what party system nationalisation is depends on whether one adopts a broad theoretical or narrow methodological perspective.

2 The undertaking of elections studies using mass surveys where there are data on electoral behaviour at the individual level are an invaluable resource to political science. Unfortunately, in many countries the number of election surveys is limited, and/or the questions
} 
nation used tends to reflect a scholar's preferences as to what best characterises party system nationalisation. Often, measures of this form of nationalisation tend to be indices or univariate statistics stemming from a data reduction procedure. A critical overview of the various measures used in this stream of research is given in Bochsler [2010].

The central advantage of using electoral data is that they facilitate making comparison across both space and time where there is greater institutional, social, economic, and historical variation, thus providing increased leverage in exploring causation. The key disadvantage of aggregate level explanations is that important details are destroyed in the process of data aggregation. Moreover, patterns evident at an aggregate level may potentially stem from many different relationships present at lower (e.g. individual) levels of analysis. Consequently, it is not always clear why party system nationalisation is higher in one state rather than another because the indices reported are national level statistics.

In this respect, it is important to note that the party system nationalisation measures used by Caramani [2004] and others have an important characteristic - they are scale variant. This means that if the degree of homogeneity of a party's electoral support is estimated using a small number of units such as regional collections of constituencies this will yield a higher nationalisation score than if subconstituency district level data were used with perhaps hundreds, or even thousands of units (see Bochsler [2010], who outlines a correction for this problem).

In practical terms this means that it is not clear what is the appropriate level of analysis [O'Laughlin 2003: 32]. This is one facet of a more general issue known as the Modifiable Areal Unit Problem (MAUP). One might reasonably argue that as constituencies are the lowest politically relevant unit, political system nationalisation scores should be estimated from data at this level. From an election outcome perspective this makes sense, as it is constituency results that determine which parties enter government. However, the construction of constituency boundaries is rarely a neutral process due to partisan considerations. In fact, another facet of MAUP is that if constituency boundaries were redrawn and the data re-analysed political system nationalisation scores would exhibit greater variation. This occurs for statistical reasons. As the number of units examined increases the level of observed variance also grows. This is because with larger numbers of units there is a greater likelihood of observing very small or very large values, and this will result in greater variation.

For this reason, one could argue that sub-constituency data has the advantage of facilitating analysis beyond the constraints imposed by electoral boundaries for individual voters. This is because aggregating individual vote choices to

asked in a series of post-election surveys are not always comparable. In addition, survey based estimates of voting behaviour are often biased due to respondents giving inaccurate answers. For these reasons, aggregated election results represent one of the few sources of consistent and accurate information about electoral behaviour across time. 
the constituency level may be one reason why party support appears so similar across a state. It could be that at the individual level the homogeneity of party support is considerably different. Therefore, by changing the unit of analysis it should be possible to see if constituency boundaries are the source of the high party system nationalisation scores observed.

In summary, the analysis of electoral data derived from geographical units requires careful consideration. Failure to recognise the impact of the unit of analysis employed on the estimation of party nationalisation statistics is likely to lead to invalid inferences. In the next section there will be a presentation of evidence illustrating the presence of party system nationalisation in the Czech Republic.

\section{Party system nationalisation in the Czech Republic}

Measures of the nationalisation of the political system tend to focus on distinct facets of electoral behaviour such as: (1) party competition, (2) territorial coverage by parties, (3) differences in party support at the regional and national levels, (4) heterogeneity of vote distribution, or (5) party aggregation effects for the entire party system, where the number of parties at the constituency and national levels are compared [see Stokes 1967; Cox 1997: 181; Jones and Mainwaring 2003; Caramani 2004: 58-70; Chhibber and Kollman 2004: 164-178; Morgernstern and Potthoff 2005; Hicken 2009: 98-115]. Each of these measures has limitations.

However, a heterogeneity measure using a Gini coefficient estimator appears to suffer least from methodological problems such as differences in party size. The Gini coefficient captures the extent to which party support varies across all constituencies. If party system nationalisation is high, then the Gini coefficient measure will reflect that political parties obtain very similar levels of support across all constituencies. As a measure of nationalisation, the inverted Gini coefficient (1 minus Gini coefficient) is used. It measures the similarity of party support across all constituencies where high values indicate a greater degree of party system nationalisation. The inverted Gini coefficient has desirable statistical properties such as mean and population size independence and symmetry. Furthermore, the inverted Gini coefficient has a fixed range (0-1), and is directly comparable across both space (countries) and time. In order to correct for methodological artefacts caused by different number of units, Bochsler [2010] has proposed a new 'standardised party nationalisation score' using a modified Gini coefficient estimator. A weighted Gini measure is estimated here in order to take account of the fact that parties have different numbers of voters across constituencies.

Turning our attention to trends in party system nationalisation in the Czech Republic since 1990, the trend evident in Table 1 suggests continuity in terms of party support and change with regard to voter turnout. More specifically, the inverted Gini coefficient estimates of the homogeneity of party support across all 
Table 1. Party system nationalisation in the Czech Republic

\begin{tabular}{lcccccccc}
\hline $\begin{array}{l}\text { Election type } \\
\text { and year }\end{array}$ & \multicolumn{9}{c}{ General Election (GE) } & & EP & GE & EP \\
\hline OF & 1990 & 1992 & 1996 & 1998 & 2002 & 2004 & 2006 & 2009 \\
ODS & .91 & - & - & - & - & - & - & - \\
ČSSD & - & .92 & .91 & .89 & .90 & .93 & .91 & .92 \\
KSČM & .76 & .88 & .91 & .93 & .95 & .95 & .92 & .91 \\
KDU-ČSL & .95 & .95 & .94 & .92 & .90 & .91 & .91 & .91 \\
SZ & .81 & .70 & .77 & .80 & .87 & .70 & .76 & .70 \\
HSD-SMS & .81 & - & - & - & .92 & .90 & .88 & .79 \\
SPR-RSČ / & .38 & .40 & - & - & - & - & - & - \\
RMS & - & .84 & .86 & .87 & - & - & - & - \\
ODA & - & .73 & .86 & - & - & - & - & - \\
US / US-DEU & - & - & - & .89 & - & - & - & - \\
Voter turnout & 1.00 & .98 & .98 & .98 & .97 & .94 & .97 & .94 \\
Mean total & .80 & .80 & .89 & .90 & .92 & .89 & .89 & .86 \\
score & & & & & & & &
\end{tabular}

Source: Election Statistics, Czech Statistical Office (http://www.volby.cz/).

Notes: The estimates are 'inverted' Gini coefficients of party support weighted according to the size of the unit of analysis for all Lower Chamber Elections (or General Elections, GE) and European Parliament elections (EP) since 1990 within the Czech Republic. The units of analysis are electoral constituencies (1990-1998, N=8; 2002-2009, N=14). These units are not constituencies for EP elections as the whole country is a single constituency. When smaller units are used instead of constituencies (76 counties + 15 Prague units, N=91; or counties divided into urban and rural areas + 15 Prague units, N=159), the results are on average lower by .02. KDU-ČSL and US-DEU ran in 2002 as an electoral coalition under the name Koalice (these figures are in the KDU-ČSL row). The mean total score is the arithmetic mean for all parties and voter turnout, and provides an overall measure of party system nationalisation.

Legend: OF: Civic Forum (umbrella movement); ODS: Civic Democrats (rightist); ČSSD: Social Democrats (leftist); KSČM: Communist Party (extreme left); KDU-ČSL: Christian Democrats (centre-right); SZ: Green Party (centre-right); HSD-SMS (a small regional party in Moravia) and SPR-RSČ / RMS: Republican Parties (nationalist); ODA/US-DEU: Union of Freedom (rightist).

constituencies reveal that the Czech party system is quite strongly nationalised. Moreover, party system nationalisation has been evident since the first post-communist elections of 1990.

The evidence presented in Table 1 reveals a key feature of Czech political parties: they do not have especially strong regional (constituency-based) heartlands. In addition, one might argue that these party system nationalisation meas- 
ures provide evidence of a 'national political culture' where party competition is essentially the same right across the Czech Republic. Also, the fact that the inverted Gini coefficients for the European Parliament Elections of 2004 and 2009 exhibit similar values to the adjacent Chamber Elections in 2002 and 2006 would seem to underscore the robustness of party system nationalisation in the Czech Republic. $^{3}$

Having examined global measures of party system nationalisation for each of the main parties across six chamber elections, the focus will now shift towards the nature of swings in electoral support across elections - another central theme within the party system nationalisation literature. Within recent Czech electoral history the change in voter turnout and party support witnessed for the general election of 2002 and the European election of 2004 was quite pronounced. Electoral participation more than halved (a drop from 65\% to 28\%) and support for the main incumbent party, the Czech Social Democrats (ČSSD), collapsed to a quarter of its previous level, i.e. fell from 33\% to $8 \%$. Given these dramatic changes in electoral behaviour across a two-year period it would seem that the power of the nationalisation process is quite remarkable, as the inverted Gini coefficients, presented in Table 1, for both elections are almost the same. ${ }^{4}$

In this article, vote switching between a general election and a European election will be used as a case study of what dynamics underpin the electoral swings that are part and parcel of a nationalised party system. Discussion of vote switching across elections in terms of party system nationalisation, as conceptualised by Caramani [2004], involves consideration of what defines this process.

\section{Party system nationalisation and vote switching}

A central feature of the American or Michigan Voter Model is the inherent stability of electoral competition in the United States. In a seminal study, it was argued that voting behaviour in America in the late 1950s was mainly determined by the presence or absence of a long-term psychological attachment to a specific party deriving from socialisation processes originating in the family [Campbell et al. 1960]. For this reason, voting and politics more generally tend to be characterised by stability rather than change.

\footnotetext{
${ }^{3}$ An alternative method of assessing the degree of territorial clustering of party support in the Czech Republic is to use a measure of spatial autocorrelation such as Moran's I. Kouba [2007] reports some evidence of spatial effects, however, sociological variables are shown to have the greatest impact on explaining variation in party choice in the Czech Republic between 1990 and 2006.

${ }^{4}$ Alternative measures of party system nationalisation are not presented here because of space constraints. The focus of this article is on exploring the individual-level foundations of a 'standard' party system nationalisation measure. A comparison of different party system nationalisation measures is given in Bochsler [2010].
} 
The search for what makes a polity stable on the basis of a national voting pattern, rather than being fragmented into regional party strongholds, led key designers of the American Voter Model such as Campbell et al. [1960], Converse [1966], and Stokes [1967] to develop a set of influential models of vote switching behaviour using aggregate data. However, Caramani [2004: 39-43] has argued that the exploration of party system nationalisation in terms of vote switching behaviour is not a productive research strategy. More will be said on this point below.

\section{Uniform vote swings and party system nationalisation}

If a party system is nationalised then it will consistently exhibit homogeneous levels of party support across consecutive elections. However, elections do differ on the basis of voter turnout and party support. This raises the question: What is the relationship between vote swings and party system nationalisation? Caramani [2004] answers this question by arguing that high levels of party system nationalisation are associated with uniform electoral swings. Thus, elections will differ on the basis of turnout and party support, but these differences occur in equal measure across all constituencies because there is a uniform electoral swing. In contrast, non-uniform swings 'are assumed to be determined exclusively by local factors and therefore do not lead to nationalisation.' In this respect, it is argued regional voting patterns 'can be explained only through the presence of forces exerting an influence at the regional or local level.'

In essence, Caramani [2004: 40] argues that if a pair of elections exhibit high levels of party system nationalisation then vote switching across such elections will be 'more or less' homogeneous. However, attempts to locate the source of such uniform electoral swings at the local or national levels have generally been unsuccessful for technical reasons. Consequently, Caramani concluded (a) that the source of uniform vote swings must be 'more or less homogeneously distributed across regions', and (b) it is better for researchers to focus on identifying the sources of stability that yield high levels of party system nationalisation rather than why voter turnout and party support varies across elections.

Therefore, in the absence of compelling empirical evidence Carmani assumes that high levels of party system nationalisation across elections are associated with uniform vote swings. This article tests this assumption by getting around previous technical limitations where the sources of uniform and non-uniform electoral swings are explored at the level of the individual voter through use of ecological inference estimates. Of course, not all elections are the same, and it is important when studying vote switching to make some comments regarding electoral behaviour in different types of elections. 


\section{Vote switching and different election types}

One of the main features of the classical theories of vote switching is that political stability is judged in terms of a 'normal' vote based on long-term criteria that is in turn typically associated with national factors. In almost all cases vote switching is defined as deviation from a true nationalised voting pattern in different types of elections. The mechanisms underpinning vote switching are seen to be numerous. It is, therefore, difficult to determine if the dynamics of electoral change are uniform across the electorate (and hence nationalised according to Caramani [2004]) with aggregate data.

It is important at this point to briefly explain why Caramani [2004: 35-39] is sceptical of examining party system nationalisation using influential vote-switching models such as variance-components analysis that employ aggregate data. Two central questions are addressed in any variance-components analysis of party system nationalisation. First, what are the sources of the forces influencing voting behaviour and are they located at the local or national level? Second, are voters more strongly influenced by factors located at the local or national levels? An analysis of variance model of data from a series of elections are used to estimate the variation in voting behaviour stemming from local or national sources in the mean vote observed in a 'typical' local electoral district.

With a variance-components analysis, the electoral swings in turnout and party support observed, regardless of their source, may be uniform (i.e. the same across the country) or non-uniform where there are localised differences. Where non-uniform vote swings exist, use of a variance-components model is problematic. This is because it is not possible for technical reasons to determine if the source of non-uniform swings originates at the local or national level [Claggett, Flanigan and Zingale 1984: 83-84]. ${ }^{5}$ Moreover, use of the variance-components methodology with data from different types of election is most likely to uncover non-uniform electoral swings as the forces (local or national) influencing voting in different contests are not likely to be the same [see Vertz, Frandeis and Gibson 1987]. This implies, as Caramani [2004: 39] argues, that individual level survey data rather than aggregate electoral statistics should be used to identify the sources of party system nationalisation when exploring non-uniform vote switching patterns.

However, as will be discussed below, using an ecological inference approach facilitates getting around methodological problems associated with making inferences using aggregate electoral results. Taking to heart the criticism made by Caramani [2004] against variance-components (vote switching) explanations of party system nationalisation, the focus here is on net electoral flows rather than

\footnotetext{
${ }^{5}$ With uniform party switching the variance-components model is a useful approach. This is because this model of party system nationalisation is able to distinguish between 'national' (evident in uniform vote switching) and 'local' (non-uniform electoral swings) voting effects.
} 
the source of electoral change. Moreover, the latent structure approach to ecological inference demonstrates that much more information may be derived from sub-national electoral data than the construction of summary statistics at the national level; and this facilitates telling a more detailed story as to how party system nationalisation evolves within states.

The strong emphasis in Caramani's [2004] work on the importance of cleavages in society determining voting patterns is the same perspective used by Thomsen [1987] to model vote switching. This line of thinking was extended in Thomsen's [1998] 'model of the direct national effect on local elections.' Here vote switching is seen to be a manifest indicator of change in party image and hence in the level of psychological attachment (a latent measure) across levels of governance. The key dynamic in this model is a feedback mechanism, which is essentially a nationalisation force that attenuates differences in electoral behaviour across different election types over time.

Such work demonstrates the merits of studying party system nationalisation using (1) homogeneity of party support measures such as the inverted Gini coefficient, and (2) vote-switching patterns across pairs of elections derived from ecological inference analysis. One could argue that Caramani's [2004] key misgivings about using vote switching to explore party system nationalisation are both empirical and theoretical in nature. His reticence draws attention to a central question: If party system nationalisation is an important social phenomenon what type of vote switching patterns should be observed, and why? Within this article we will take as a case study vote switching across national and European elections. This is because the election results suggest that these contests are treated very differently by voters, and there is consequently considerable scope for studying vote switching. ${ }^{6}$

Therefore, in the following sections vote switching between the 2002 general election and subsequent European election in 2004 in the Czech Republic will be examined as a means of exploring the individual-level basis of party system nationalisation.

\section{Ecological inference and party system nationalisation}

The act of voting is primarily an individual-level phenomenon. Consequently, the usefulness of providing explanations of electoral behaviour for whole national electorates is limited if it does not address what individual level motivations de-

\footnotetext{
${ }^{6}$ This approach is consonant with the Second Order Election Thesis outlined briefly in the introduction. SOET is currently the most influential explanation of vote switching in this context [Reif and Schmitt 1980; Reif 1984; van der Eijk and Franklin 1996; Carrubba and Timpone 2005]. This perspective has been criticised by Blondel, Svensson and Sinnott [1998] and Manow [2005].
} 
termine total electoral phenomena such as party system nationalisation. Explanations of party system nationalisation are generally aggregate-level accounts of electoral behaviour and do not address directly the question of how the actions of individual voters may yield remarkably consistent levels of party support across all constituencies and across many elections. If actual individual level voting data were available it would be possible to examine how the aggregation of single votes results in a nationalised pattern of party support. In the absence of such data due to the secrecy of the ballot there is the temptation to simply infer individual-level motivations from district level election results.

Transposing aggregate-level patterns of voting behaviour to the individual level through a simple process of correlation of aggregate units is problematic and is known as the 'ecological inference fallacy' [King 1997]. For this reason, macro-sociological explanations of party system nationalisation cannot be simply imputed to the level of the citizen. In order to make valid inferences at the individual level from district level electoral data, it is necessary to specify how the actions of single voters yield the constituency-level patterns observed.

A central feature of Caramani's [2004] account of party system nationalisation in Western Europe is that changes in electoral behaviour across a pair of adjacent elections may be reasonably assumed to occur through a uniform electoral swing. In this study, the assumption that high levels of party system nationalisation are associated with uniform electoral swings will be examined using an ecological inference that is currently the best means of estimating individual vote switching using aggregated data [Park 2008: 42, 76-77, 116].

The method of ecological inference we are going to use (Thomsen's latent structure approach) is explicitly designed to explore vote switching in a multiparty environment such as the Czech Republic using district level electoral data [Thomsen 1987, 1991]. Here patterns evident in aggregated electoral data are used to make inferences about individual-level vote choices. Moreover, it is assumed that the vote-switching patterns observed result from a set of latent factors such as those proposed by Caramani [2004], i.e. cleavages associated with economic left-right orientation, divisions based on social class, religion, etc. In addition, it is expected that party choice in both national and European elections is largely driven by the same (left-right) motivations. Therefore, the determinants of party choice and turnout are inherent within the voting switching patterns; and are thus not directly observed.

It is now appropriate to outline in an informal manner the ecological inference estimator used in this study. The mathematical details of the latent structure approach are described in Thomsen [1987, 1999] and are not presented here in order to keep the discussion within reasonable bounds [see also Park 2008: 31-38, 53-55]. 


\section{Ecological inference using a latent structure approach}

Party choice in elections may be viewed as being a product of the degree to which a citizen feels some sense of attachment to a particular political party. In this situation, the percentage vote received by a specific party in each electoral district is explained in terms of the propensity of voters to support parties in a consistent manner across time.

Consequently, the loyalty and defection rates observed across aggregated units such as districts and constituencies are determined by the unobserved level of partisanship, i.e. a long-term emotional attachment to a particular party, among citizens. In many countries such as the Czech Republic, the level of party attachment is the most powerful predictor of vote choice at the individual level [Linek and Lyons 2007: 196; Lebeda et al. 2007: 208; Linek 2009]. Such unobserved partisanship is evident in the level of party support observed in elections.

Treating aggregated electoral data as indicators of a latent partisanship suggests that Principal Components Analysis (PCA, often also called 'factor analysis') is a useful procedure for building an ecological inference model of vote switching across a series of elections. Here the PCA ecological models represent partisanship in terms of the loyalty or defection rates across two or more elections, while the factor itself represents the level of psychological attachment to a party, or partisanship, at the district level.

Substantively, it makes sense to model electoral transition rates in a manner where past vote choice helps determine subsequent electoral behaviour [Achen and Shively 1995: 167-168]. One disadvantage of using ecological factor analysis across a series of elections is that the structure of electoral behaviour remains the same across time. In short, ecological factor analysis assumes stability within the electorate. Quite obviously, electoral change is also important and in order to study the dynamics of party support across elections a pooled regression model is more appropriate.

It is important at this point to outline in a brief and informal manner the logic of a latent structure approach to ecological inference. Here a general factor analytic modelling setup is employed. To keep matters simple let us consider a two-party system where everyone votes. A factor analysis of such a system may be represented informally with the simple model shown in Figure 2. The top part of this figure represents what is observed and the bottom illustrates the analytical (latent factor analysis) perspective adopted in this article.

The term 'Vote for a party' refers to the proportion of the vote obtained by one of the parties in a constituency for a specific election. Thus, according to our simple model, vote for party 1 is the sum of observed partisan loyalty and defection from party 2. Party loyalty and defection are interpreted here as observed measures of the level of long-term psychological attachment (in a constituency or electoral district) to a party, and represents something like a 'standing decision'.

This attachment to a party is not directly observable in official election statistics. It is in fact a latent variable that is known from election studies based on 
Figure 1. Latent structure approach to ecological inference to modelling vote switching

\begin{tabular}{|c|c|c|c|c|c|c|}
\hline Vote for party 1 & $=$ & $\begin{array}{c}\text { Loyalty among } \\
\text { party 1's identi- } \\
\text { fiers }\end{array}$ & + & $\begin{array}{l}\text { Gains made by } \\
\text { party } 1 \text { through } \\
\text { defection from } \\
\text { party } 2\end{array}$ & + & Error \\
\hline $\begin{array}{c}\text { Latent factor: } \\
\text { party attachment }\end{array}$ & & $\begin{array}{l}\text { Factor score 1: } \\
\text { partisan loyalty }\end{array}$ & & $\begin{array}{c}\text { Factor score 2: } \\
\text { partisan defection }\end{array}$ & & $\begin{array}{c}\text { Unaccounted vari- } \\
\text { ation in voting for } \\
\text { party } 1\end{array}$ \\
\hline
\end{tabular}

Source: Achen and Shively 1995: 167-168.

Notes: This is a simplified linear regression model representation of the logic of employing official election statistics to make party switching estimates across a number of elections. The first row denotes the model and the bottom row the substantive interpretation.

mass survey data to strongly determine vote choice across many different elections. Of course, party loyalty and defection rates are not perfect predictors of vote choice and so this simple model will have error. Here the error is assumed to have a mean of zero and is uncorrelated with the vote for party 1 (the dependent variable). These are important statistical assumptions necessary for estimating a factor analysis (PCA) model.

This model may be estimated using a standard PCA methodology and its interpretation at the individual level is straightforward where, as noted earlier, (1) the factor loadings measure loyalty to, or defection from, a party and (2) the factor scores represent partisanship within the district. In summary, vote for a party in a current election is equal to the net flow of votes across elections plus the general level of party attachment within the district [Achen and Shively 1995: 173-174].

Using ecological factor analysis in this manner yields estimates of party attachment transition rates rather than the substantively more interesting voter transition rates. However, it is possible to calculate voter transition rates from party attachment transition estimates. It should be noted that this approach assumes that party attachment is dichotomous in nature, i.e. a voter feels attached to a party or they do not. This is an unrealistic assumption. Fortunately, the latent structure model of ecological inference may be extended to treating partisanship as a continuous variable ranging from very strong, to strong, to medium, to weak, to none at all.

Turning for a moment to some important technical details, if it is assumed that the probability distribution of voting for a single party in any district is normal (Gaussian), then the estimates derived from an ecological factor analysis model of party support (i.e. proportions transformed to a probit or logit scale) are correlated. Therefore, the observed vote proportions are simply a division (determined by the number of parties examined plus the decision not to vote) of 
each of these normal distributions. In statistics, the correlation between normal distributions is well understood and is known as tetrachoric correlation. Using tetrachoric correlation it is possible to employ the concept of a continuous underlying party attachment to estimate voter transition rates.

In summary, the latent approach to ecological inference argues that if party choice is primarily determined by the level of psychological attachment to a party that in turn is typically associated with structural cleavages such as class, religion, and urban/rural [Lipset and Rokkan 1967; Caramani 2004]; then it is possible to simplify the relationship between voting patterns at the aggregate and individual levels by making two assumptions that make model estimation tractable. These assumptions are: (a) the determinants of vote choice at the individual and aggregate levels are the same, i.e. there is isomorphism, and (b) the variation explained by the latent party attachment factor has a similarly high value at the individual and aggregate levels yielding a high variance ratio.

The assumption of isomorphism means that the same latent dimensions that describe the variations across individuals within each electoral district should also describe the variation across homogenous political regions within a state. This is more likely for small areas like local districts than for larger areas like constituencies/regions. It is also more likely within functionally homogeneous regions that are defined in terms of specific cleavage structures such as left-right. In such politically homogeneous regions constant model parameter values across all individuals may be assumed.

The key point here is that it is possible to use district-level election results to make estimates of vote switching at the level of the individual voter if certain assumptions (i.e. isomorphism and a high variance ratio) are made and shown to be valid. A central consideration here is identifying clusters of electoral districts that exhibit the same voting patterns that are indicative of localised 'political cultures'. Identification of local political cultures from district level electoral data is achieved using a data reduction technique such as hierarchical cluster analysis.

The validity of such assumptions is often context specific implying that a good estimation strategy in one situation may be inappropriate in another. Fortunately, Thomsen's [1987, 1998] latent structure approach to vote switching matches closely in theoretical terms with Caramani's [2004] conceptualisation of party system nationalisation; thereby strengthening our confidence in the applicability of this form of ecological inference to our research question.

\section{Data and analysis}

The research strategy adopted in this article involves integrating the dynamics of vote switching across a pair of elections that exhibit similar levels of party system nationalisation. The essential features of this research strategy are presented in Figure 2. The upper part of Figure 2 outlines the logic of how an analysis of vote 


\section{Figure 2. Overview of party system nationalisation measurement and analysis of vote switching across a pair of elections}

\begin{tabular}{|c|c|c|c|c|c|}
\hline Level of analysis & Election $t_{1}$ & & Vote switching $t_{1}-t_{2}$ & & Election $t_{2}$ \\
\hline Individual & Voter $t_{1}$ & $\Rightarrow$ & $\begin{array}{l}\text { Unknown, values } \\
\text { estimated using } \\
\text { ecological inference } \\
\text { method }\end{array}$ & $\Rightarrow$ & Voter $t_{2}$ \\
\hline \multirow{3}{*}{ Aggregation } & $\sqrt{7}$ & & $\uparrow$ & & 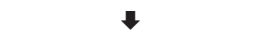 \\
\hline & Constituency $t_{1}$ & & $\begin{array}{l}\text { Homogeneous politi- } \\
\text { cal regions used to es- } \\
\text { timate vote switching } \\
\text { at individual level* }\end{array}$ & & Constituency $t_{2}$ \\
\hline & 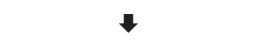 & & $\downarrow$ & & $\sqrt{n}$ \\
\hline State & Total $t_{1}$ & $\Rightarrow$ & $\begin{array}{l}\text { National vote switch- } \\
\text { ing estimates }\end{array}$ & $\Rightarrow$ & Total $t_{2}$ \\
\hline Concept & $\begin{array}{c}\text { Party system } \\
\text { nationalisation } t_{1}\end{array}$ & & $\begin{array}{l}\text { National electoral } \\
\text { swing }^{* *}\end{array}$ & & $\begin{array}{c}\text { Party system } \\
\text { nationalisation } t_{2}\end{array}$ \\
\hline \multicolumn{6}{|l|}{ Methodology } \\
\hline Mechanism & $\begin{array}{l}\text { Proportion of vote } \\
\text { won by each party is } \\
\text { the same across all } \\
\text { constituencies }^{\#}\end{array}$ & & $\begin{array}{l}\text { Vote switching may } \\
\text { be the same across } \\
\text { all regions, or may be } \\
\text { region specific }{ }^{\# \#}\end{array}$ & & $\begin{array}{l}\text { Proportion of vote } \\
\text { won by each party is } \\
\text { the same across all } \\
\text { constituencies }^{\#}\end{array}$ \\
\hline $\begin{array}{l}\text { Type of } \\
\text { analysis }\end{array}$ & $\begin{array}{l}\text { Static, measure is for } \\
\text { one election }\end{array}$ & & $\begin{array}{l}\text { Dynamic, vote choice } \\
\text { across a pair of elec- } \\
\text { tions }\end{array}$ & & $\begin{array}{c}\text { Static, measure is for } \\
\text { one election }\end{array}$ \\
\hline $\begin{array}{l}\text { Unit of } \\
\text { analysis }\end{array}$ & Constituency & & Individual voter & & Constituency \\
\hline Measure & $\begin{array}{l}\text { State level (Inverted } \\
\text { Gini coefficient } t_{1} \text { ) }\end{array}$ & & $\begin{array}{c}\text { Individual vote } \\
\text { switching estimates }\end{array}$ & & $\begin{array}{l}\text { State level (Inverted } \\
\text { Gini coefficient } t_{2} \text { ) }\end{array}$ \\
\hline
\end{tabular}

Source: Authors' review of the theory and methodology of party system nationalisation and use of latent structure ecological inference to examine vote switching.

Notes: The black vertical arrows pointing downwards indicate the data aggregation process where individual votes are summed to the constituency level, and thereafter constituency results are aggregated to yield national electoral results. The white horizontal arrows illustrate that the mechanism(s) underpinning party system nationalisation operate across elections and will be evident in vote switching patterns.

* Homogenous political regions (or distinct sub-national political cultures) are derived from a cluster analysis of electoral results of sub-constituency units.

** Observed changes at the aggregate level in voter turnout and party across two consecutive elections $\left(t_{1-2}\right)$. This official data stems from vote switching by individual electors that are not directly observed but may be inferred using an ecological inference estimator.

\# Absolute level of turnout and party support is election specific.

\# The party system nationalisation literature does not specify if vote switching between pairs of elections follows (a) a uniform national pattern, or (b) exhibits inter-constituency / regional differences. 
switching between a pair of elections can provide information about the relationship between party system nationalisation and the voter. It is important to note here that party system nationalisation measures are estimated using constituency level data $(\mathrm{N}=8 / 14)$, while estimates of vote switching at the level of the individual voter were derived from district electoral data $(\mathrm{N}=159)$ that have been aggregated to four regions on the basis of cluster analysis. ${ }^{7}$

The bottom part of Figure 2 contrasts the methodological features of measuring party system nationalisation for two elections and the individual vote switching dynamics that link these two national contests. The essential point here is that aggregated vote data which have been clustered into regions that exhibit a common 'political culture' may be used to estimate vote-switching patterns at the level of the individual voter. This ecological inference procedure is the basis for studying the link between party system nationalisation and the voter, which is the central goal of this research.

The latent structure approach to ecological inference is based on having stable sub-national units where aggregated electoral data are available for a pair of elections. In the Czech Republic, data were assembled from the official electoral sources of results from 159 geographical units (i.e. all counties which were divided into urban and rural areas) for the 2002 general election and 2004 European elections. As noted in the last section, one of the key assumptions of the latent structure approach to ecological inference is the identification of homogeneous geographic areas where the factors underlying electoral behaviour can be reasonably inferred to be the same.

\section{Identification of local political cultures}

As noted above, in order to identify these homogeneous electoral regions a hierarchical cluster analysis of district level electoral results in the Czech Republic was performed. Election results for nine parties that won seats in the 2002 Chamber Elections or the 2004 European Elections plus voter turnout in both elections were analysed. The electoral data were then subjected to a hierarchical cluster analysis using: (a) 'block distance' because it is less affected by outliers in the data and yields more robust solutions, and (b) 'within-group linkage' to ensure that the clusters are as internally homogeneous as possible. A number of cluster solutions (one to five clusters) were examined and the resulting vote switching matrices were cross-validated with survey estimates. ${ }^{8}$

\footnotetext{
7 The regional (kraje) division of the Czech Republic increased from 8 to 14 units in 2001. This change coincided with reform of local and regional government.

8 A comparison was made with estimates from an exit poll and an academic post-election survey. This cross-validation revealed that the ecological inference estimates are reasonable. Some details are given in the next sub-section. For more information see Linek and Lyons [2007] and Lyons [2008].
} 
Figure 3. Political regions within the Czech Republic derived from a hierarchical cluster analysis of electoral results for the Chamber Elections of 2002 and the European Parliament Elections of 2004

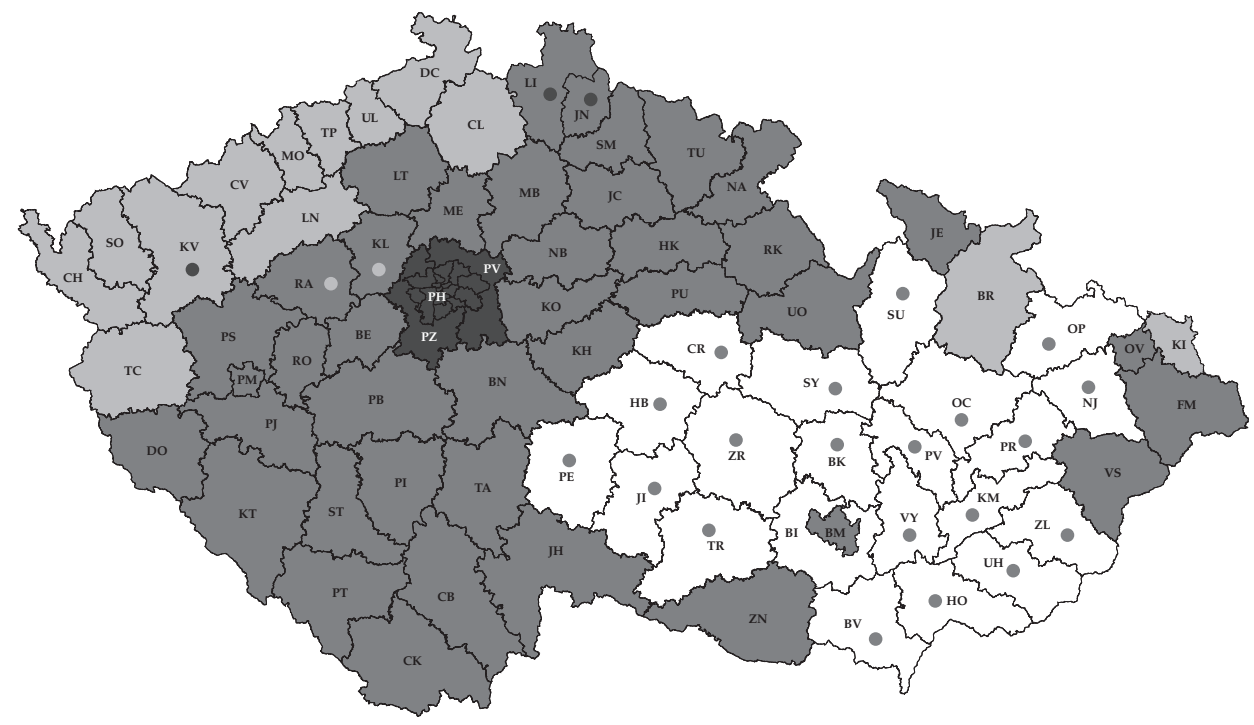

Source: Election Statistics, Czech Statistical Office (http://www.volby.cz/).

Notes: The classification of counties and county towns is based on a cluster analysis of the election results of 2002 and 2004. The regions are numbered as follows (1) Bohemia and urban Moravia (medium grey); (2) Rural Moravia (white); (3) Prague (dark grey); (4) Northwest Bohemian borderlands (light grey). Districts with different coloured solid circles at their centre indicate areas where there were urban/rural differences.

This analysis combined with additional contextual information suggested that a four-cluster solution was most appropriate. Figure 3 shows the geographical distribution of the four local political cultures identified: (1) Bohemia and urban Moravia, (2) Rural Moravia, (3) Prague, and (4) Northwest Bohemia. The cluster analysis does not produce results that are definitive in terms of matching with expert evaluations. This is because the cluster analysis employs purely statistical criteria to find homogeneous regions of 'political culture'.

Moreover, this statistical classification only uses the voting patterns for two consecutive elections to do this task. Unsurprisingly, the classification of 159 units yields some unexpected groupings. The goal of this analysis is not to produce an accurate socio-political map of the Czech Republic, but to create reasonably homogeneous regions characterised by a 'local political culture' in order to estimate vote-switching patterns using Thomsen's [1987] ecological inference methodology. In sum, the cluster labels used here are used here in a heuristic manner and should not be interpreted as being definitive. 
Therefore, the political geography 'misclassifications' evident in Figure 3 (e.g. Prague cluster includes cities Liberec and Jablonec nad Nisou) do not form a core element in the argument presented. A similar analysis using vote switching between the 2002 and 2006 general elections exhibits exactly the same pattern demonstrating that this regional structure is a stable one. In short, the results of the cluster analysis shown in Figure 3 may be interpreted as demonstrating the importance of socio-historical background. This is a feature that is emphasised in Caramani's [2004] account of party system nationalisation. One of the key implications of the clustered pattern evident in Figure 3 is that highly nationalised party systems such as the Czech Republic can exhibit localised political cultures that have a strong territorial basis.

In the next sub-section, the results of an ecological inference analysis of vote switching between the general election of 2002 and the European election of 2004 will be presented. It is important to stress that these estimates represent the behaviour of individual voters. Discussion of individual vote-switching behaviour will be restricted to the flow of support between government and opposition parties, and changes in voter turnout in order to keep the presentation to a reasonable length.

\section{Vote switching between parties and abstention}

Before presenting the ecological inference estimates of vote switching a brief comment on the validity of these results is warranted. The ecological inference estimates were compared with the results of two mass surveys using a standard measure called the Duncan Dissimilarity Index. This index is essentially a means of comparing two vote-switching tables. The differences in the cells across the two tables are added together and thereafter a mean difference is estimated. This represents the average (or total) difference in vote switching estimates between the two tables examined. Estimation of the Duncan Dissimilarity Index reveals that the ecological inference estimates are very similar to the survey measures of vote switching between 2002 and 2004. In fact, the mean differences between the two surveys and the ecological inference results were less than one percent $(0.28$ and $0.56 \%)$. To put this in perspective, the mean difference in vote-switching estimates for the two surveys examined was of a similar magnitude $(0.56 \%)$. In short, our cross-validation exercise reveals that the ecological inference estimates are reasonable.

One of the central concerns in the study of elections is the success of large (and often governing) parties in maintaining their electoral support. Swings away from the government to the opposition are often used by electoral commentators to evaluate incumbent parties' performance. ${ }^{9}$ In addition, changing levels of voter

${ }_{9}$ Governing parties (ČSSD, KDU-ČSL and US-DEU) are defined here as those who were in office when the elections to the European Parliament took place on 11-12 June 2004. 


\section{Figure 4(a). Comparison of voter loyalty for government and opposition parties} between 2002 and $2004(\%)$

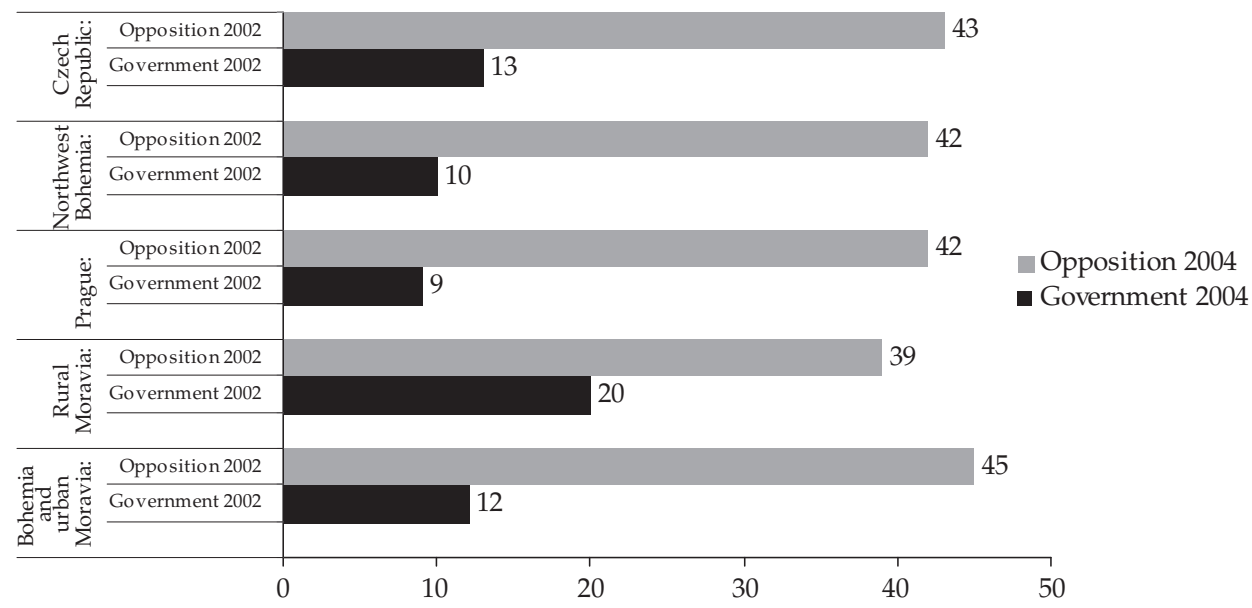

Source: Election Statistics, Czech Statistical Office (http://www.volby.cz/).

Notes: The data are ecological inference estimates derived from the official elections results. The estimates in this figure indicate the loyalty of government and opposition party voters in the elections of 2002 and 2004. This figure should be interpreted as follows: $43 \%$ of those who voted for opposition parties in 2002 also voted opposition parties in 2004 across the Czech Republic. In contrast, 13\% of those who voted for government parties in 2002 did so again in 2004.

turnout are often interpreted as indicators of popular attitudes toward the political class and the system of governance.

The ecological inference results shown in Figure 4(a) show that more than half $(54 \%)$ of those who voted for opposition parties in 2002 (ODS, KSČM) decided not to vote in 2004, while 43\% remained loyal and less than one-in-twenty (3\%) switched to government parties. ${ }^{10}$ Turning our attention now to incumbent government parties (ČSSD, KDU-ČSL, US-DEU) we find that the pattern of vote switching was more diverse.

\footnotetext{
All other parties in the (lower) Chamber of Deputies are considered to constitute the 'opposition' (ODS, KSČM).

${ }^{10}$ It is important to note that unlike the standard measures of party system nationalisation such as the inverted Gini coefficient, the ecological vote-switching coefficients reported in Figure 4 are 'estimates' and not 'measures'. The vote switching values are based on statistical inference and are not measured with certainty. Park [2008: 63-65] demonstrates how it is possible to calculate standard errors using bootstrapping for the Thomsen estimator. Standard errors are not shown as they do not affect the substantive argument presented.
} 
Figure 4(b). Vote switching between government and opposition parties, 2002-2004

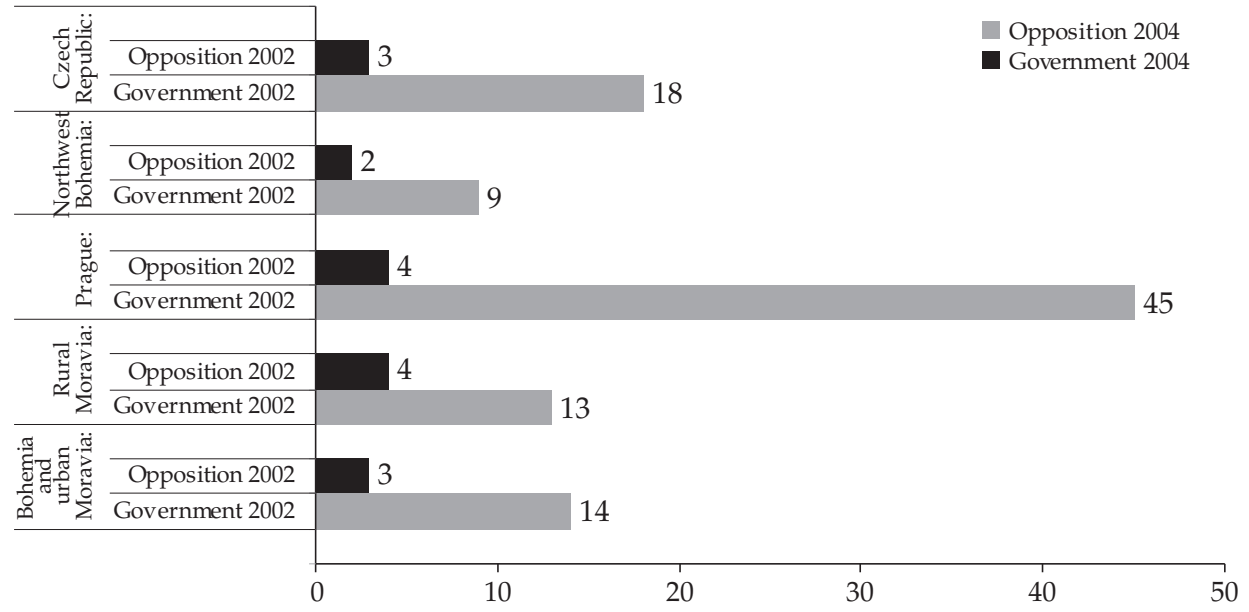

Source: Election Statistics, Czech Statistical Office (http://www.volby.cz/).

Notes: The data are ecological inference estimates derived from the official elections results. The estimates in this figure indicate how many voters voted for government parties in 2002 and supported an opposition party in 2004. In this figure within Prague one observes that $45 \%$ of the voters for government parties in 2002 voted for an opposition party in 2004; while 4\% voted for an opposition party in 2002 and supported a government party in 2004.

If we take each of the strategies open to voters, we observe in Figure 4(b) considerable regional variation. For example, $45 \%$ of government party supporters in Prague switched to opposition parties in 2004. This form of party switching in Prague was more than twice the national rate, i.e. $18 \%$. Differential rates of abstention for government party switchers also exhibit strong regional differences. Figure $4(\mathrm{c})$ reveals that in Northwest Bohemia $81 \%$ of the electorate did not vote, while in Prague the abstention rate was considerably lower (47\%). Voters living in Rural Moravia, as shown in Figure 4(a), were unique in their relatively high level of party loyalty (i.e. one-in-five) in comparison to other regions where party loyalty varied between $9 \%$ and $12 \%$.

Overall, the evidence presented in Figure $4(\mathrm{a}-\mathrm{c})$ demonstrates that there are important regional differences in individual-level vote-switching behaviour across general and European elections in the Czech Republic. The ecological inference estimates reveal three key differences. First, the typical voter residing in Rural Moravia as noted above exhibited a relatively high level of government loyalty (20\% vs. $13 \%$ at the national level). Second, the average voter living in Prague had a comparatively high level of switching from government to opposition parties when compared to the national rate ( $45 \%$ vs. $18 \%)$. Lastly, the Prague-based 
Figure 4(c). Differential abstention rates in the elections of 2002 and 2004 in terms of voting for government parties in 2002

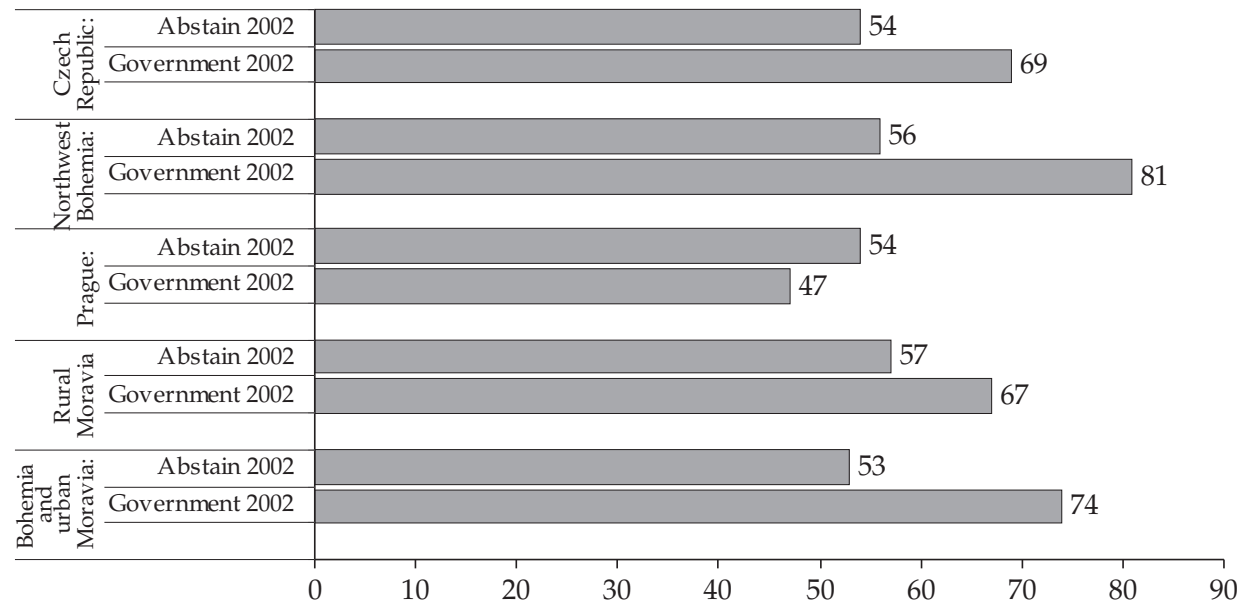

Source: Election Statistics, Czech Statistical Office (http://www.volby.cz/).

Notes: The data are ecological inference estimates derived from the official elections results. The estimates shown in this figure indicate the rate of abstention for voters in the 2002 and 2004 elections. For example, $69 \%$ of those who voted for the government in 2002 did not vote in 2004 across the Czech Republic. A little more than half (54\%) of those who did not vote in 2002 also did not vote in 2004. A salient feature of this figure is the pattern evident in Prague is unique. In Prague, the rate of consistent abstention (54\%) in 2002 and 2004 was greater than the abstention among government supporters (47\%).

Elsewhere the converse is observed.

voter had a much lower level of differential abstention among government party voters than the rest of the country ( $47 \%$ vs. $69 \%$ ). These three regional differences demonstrate at the level of the individual voter that it is possible to have a consistently high level of party system nationalisation and also have non-uniform electoral swings.

Such evidence suggests that Caramani's [2004: 39-40] view that party system nationalisation is primarily associated with uniform electoral swings is not always the case. Moreover, Caramani's criticism that variance-components models of non-uniform vote switching cannot locate the sources of these swings does not apply to ecological inference models. This is because the source of vote switching is the individual voter. Here non-uniform vote swings are associated with individual voters who live in different territorial regions that exhibit a local political culture. 


\section{Conclusion}

The aggregate electoral evidence for the Czech Republic (1990-2009) reveals that the Czech party system is one of the most nationalised in Central and Eastern Europe [Bochsler 2010: 165]. The inverted Gini coefficient measures of party system nationalisation suggest that the same forces of political stability operate across all elections. At first glance, this is a puzzling finding because different types of elections exhibit very different levels of voter turnout and party support. This is especially evident when comparing general and European election results.

Caramani [2004] and others have argued that a highly nationalised party system is compatible with considerable variations in electoral behaviour across elections. This is because the inter-election differences in participation and party choice do not exhibit systematic regional patterns. In short, localised vote switching evident across pairs of elections are randomly distributed across all constituencies. As a result, net electoral swings at the national level are uniform in nature and party nationalisation statistics do not change from election to election.

Within this article we have tested Caramani's [2004: 39-40] assumption that party system nationalisation is primarily associated with uniform vote-switching patterns. Rather than using a variance-components estimator where the goal is to decompose electoral swings into local and national components, this study has used an ecological inference approach to estimate vote switching at the individual level. This methodology avoids the difficulties identified by Caramani regarding identification of the sources of vote switching.

Using the Czech Republic as a typical example of a nationalised party system where there are large differences in the electoral behaviour observed in general and European elections, this study demonstrates that party system nationalisation is not always associated with uniform vote switching patterns. This finding is substantively important because it shows that all voters in nationalised party systems do not evaluate electoral choices in the same manner.

By exploring the territorial features of vote switching behaviour the evidence presented demonstrates that party system nationalisation should not be equated with a homogeneous electorate who exhibit uniform vote switching behaviour. This research also reveals that country wide measures of party system nationalisation should not be interpreted as showing that regional voting patterns are unimportant in understanding the dynamics of electoral choice. Moreover, the use of ecological inference methods for studying uniform and non-uniform vote switching open up many opportunities for improving our understanding of how individual vote choices within a specific local context contribute to highly nationalised party systems.

The approach presented in this study should be extended in future work to test rival causal explanations of (uniform and non-uniform) vote switching and to examine a greater number of elections. Future work should also investigate if the underlying partisan bases of party system nationalisation vary consistently 
across pairs of different election types (i.e. general-European elections; general-regional elections; regional-European elections, etc.). Looking beyond single country studies such as the Czech Republic, future research should evaluate the degree to which different institutional contexts such as electoral system type influence party system nationalisation through uniform and non-uniform vote switching behaviour.

PAt Lyons is a member of the Department of Political Sociology, Institute of Sociology, Academy of Sciences of the Czech Republic. His main areas of research are public opinion, political attitudes, electoral and legislative behaviour, and party politics. Recently he has completed a book length study of public and elite attitudes toward political reform during the Prague Spring era, which also compares Czech citizens' attitudes toward democracy in 1968 and 2008 (Mass and Elite Attitudes during the Prague Spring Era: Importance and Legacy, Prague 2009).

LUKÁš LINEK is a senior researcher in the Department of Political Sociology, Institute of Sociology, Academy of Sciences of the Czech Republic. His main research interests are voting behaviour, political parties and mass political attitudes. He has recently published a book on the evolution of political attitudes in the Czech Republic over the last two decades (Zrazení snu? Struktura a dynamika postojů k politickému režimu a jeho institucí a jejich důsledky [Betrayal of the Dream? The Structure and Dynamics of Attitudes toward the Political Regime, and its Institutions and their Consequences], Prague 2010).

\section{References}

Achen, C. H. and W. Philips Shively. 1995. Cross-level Inference. Chicago, IL: University of Chicago Press.

Alemán, E. and M. Kellam. 2008. 'The Nationalization of Electoral Change in the Americas.' Electoral Studies 27 (2): 193-212.

Blondel, J., P. Svensson and R. Sinnott. 1998. People and Parliament in the European Union: Democracy, Participation and Legitimacy. Oxford: Oxford University Press.

Bochsler, D. 2010. 'Measuring Party Nationalisation: a New Gini-based Indicator that Corrects for the Number of Parties.' Electoral Studies 29 (1): 155-168.

Campbell, A. 1960. 'Surge and Decline: a Study of Electoral Change.' Public Opinion Quarterly 24: 397-418.

Campbell, A., P. E. Converse, W. E. Miller and D. E. Stokes. 1960. The American Voter. New York: John Wiley \& Sons, Inc.

Caramani, D. 2004. The Nationalisation of Politics: the Formation of National Electorates and Party Systems in Western Europe. Cambridge: Cambridge University Press.

Carrubba, C. and R. J. Timpone. 2005. ‘Explaining Vote Switching across First- and Second-order Elections. Evidence from Europe.' Comparative Political Studies 38 (3): 260-281. 
Chhibber, P. and K. Kollman. 1998. 'Party Aggregation and the Number of Parties in India and the United States.' American Political Science Review 92 (2): 329-342.

Chhibber, P. and K. Kollman. 2004. The Formation of National Party Systems: Federalism and Party Competition in Canada, Great Britain, India and the United States. Princeton, NJ: Princeton University Press.

Claggett, W., W. Flanigan and N. Zingale. 1984. 'Nationalization of the American Electorate.' American Political Science Review 78 (1): 77-91.

Converse, P. E. 1966. 'The Concept of a Normal Vote.' Pp. 9-39 in Elections and the Political Order, edited by A. Campbell, W. E. Miller and D. E. Stokes. New York: Wiley.

Cox, G. W. 1997. Making Votes Count. New York: Cambridge University Press.

Cox, G. W. 1999. 'Electoral Rules and Electoral Coordination.' American Review of Political Science 2: 145-161.

Ferree, K. E. 2010 (in print). 'The Social Origins of Electoral Volatility in Africa.' British Journal of Political Science.

Hicken, A. 2009. Building Party Systems in Developing Democracies. Cambridge: Cambridge University Press.

Jones, M. P. and S. Mainwaring. 2003. 'The Nationalization of Parties and Party Systems: An Empirical Measure and Application to the Americas.' Party Politics 9 (2): 139-166.

King, G. 1997. A Solution to the Ecological Inference Problem. Princeton, NJ: Princeton University Press.

Kouba, K. 2007. ‘Prostorová analýza českého stranického systému. Institucionalizace a prostorové režimy' (Spatial Analysis of the Czech Party System: Institutionalisation and Spatial Regimes). Sociologický časopis/Czech Sociological Review 43 (5): 1017-1037.

Lebeda, T., L. Linek, P. Lyons and K. Vlachová. 2007. 'Závěr: Co rozhodlo volby do Poslanecké sněmovny v roce 2006 a co jsme se dozvěděli o volebním chování v ČR?' (Conclusion: What Decided the Parliamentary Elections in 2006 and What We Learned about Voting Behaviour in the Czech Republic). Pp. 203-214 in Voliči a volby 2006, edited by T. Lebeda, L. Linek, P. Lyons, K. Vlachová et al. Prague: Sociologický ústav AV ČR.

Linek, Lukáš. 2009. 'Jak měřit stranickou identifikaci?' (How to Measure Party Identification?) Data a výzkum - SDA Info 3 (2): 187-210.

Linek, L. and P. Lyons. 2007. 'What Can Ecological Inference Tell Us about the SecondOrder-Election-Thesis in the Czech Republic and Slovakia.' Pp. 327-369 in European Elections after Eastern Enlargement: Preliminary Results from the European Election Study 2004, edited by M. Marsh, S. Mikhaylov and H. Schmitt. Mannheim: University of Mannheim, MZES.

Lipset, S. M. and S. Rokkan. 1967. 'Cleavage Structures, Party Systems, and Voter Alignments.' Pp. 1-64 in Party Systems and Voter Alignments: Cross-national Perspectives, edited by S. M. Lipset and S. Rokkan. New York: The Free Press.

Lyons, P. 2008. 'Ekologické usuzovaní: explorace metody latentní struktury za využití volebních dat z ČR' (Ecological Inference: Exploring Latent Structure Methods Using Election Data from the Czech Republic). Data a výkum - SDA Info 2 (1): 49-76.

Manow, P. 2005. 'National Vote Intention and European Voting Behaviour, 1979-2004: Second Order Election Effects, Election Timing, Government Approval and the Europeanization of European Elections.' Discussion Paper 05/11. Köln, Germany: Max-Planck-Institut für Gesellschaftforchung (MPIfG).

Morgenstern, S. and R. F. Potthoff. 2005. 'The Components of Elections: District Heterogeneity, District-Time Effects, and Volatility.' Electoral Studies 24: 17-40.

Morgenstern, S. and S. M. Swindle. 2005. 'Are Politics Local? An Analysis of Voting Patterns in 23 Democracies.' Comparative Political Studies 38 (2): 143-170. 
O'Laughlin, J. 2003. 'Spatial Analysis in Political Geography.' Pp. 30-46 in A Companion to Political Geography, edited by J. Agnew, K. Mitchell and G. Ó Tuathail. Malden, MA: Blackwell Publishing.

Park, W. 2008. 'Ecological Inference and the Aggregate Analysis of Elections.' PhD dissertation, Department of Political Science, University of Michigan, Ann Arbor, Michigan, USA.

Reif, K. and H. Schmitt. 1980. 'Nine Second-Order National Elections - a Conceptual Framework for the Analysis of European Election Results.' European Journal of Political Research 8 (1): 3-44.

Reif, K. 1984. 'National Electoral Cycles and European Elections 1979 and 1984.' Electoral Studies 3: 244-255.

Rokkan, S. 1970. Citizens, Elections, Parties: Approaches to the Comparative Study of the Processes of Development. New York: David McKay Co.

Samuels, D. J. 2000. 'The Gubernatorial Coattails Effect: Federalism and Congressional Elections in Brazil.' Journal of Politics 62: 240-253.

Stokes, D. E. 1967. 'Parties and the Nationalization of Electoral Forces.' Pp. 182-202 in The American Party Systems: Stages of Political Development, edited by W. N. Chambers and W. D. Burnham. New York: Oxford University Press.

Thomsen, S. R. 1987. Danish Elections 1920-1979: A Logit Approach to Ecological Analysis and Inference. Arrhus: Politica.

Thomsen, S. R. 1998. 'Impact of National Politics on Local Elections in Scandinavia.' Scandinavian Political Studies 21 (4): 325-345

Thomsen, S. R. 1999. 'Ecological Inference with the Multiple Logit Model.' Working Paper, February 1999, Department of Political Science, Aarhus University, Universitetsparken, DK-8000, Denmark.

Thomsen, S. R., S. Berglund and I. Wörlund. 1991. 'Assessing the Validity of the Logit Method for Ecological Inference.' European Journal of Political Research 19: 441-477.

Tiemann, G. 2005. The Nationalization of East European Party Systems. Frankfurt-an-derOder: Frankfurter Institut für Transformationsstudien.

van der Eijk, C. and M. N. Franklin. 1996. Choosing Europe? The European Electorate and National Politics in the Face of Union. Ann Arbor, MI: University of Michigan Press.

Vertz, L., J. Frendreis and J. Gibson. 1987. 'Nationalization of the Electorate in the United States.' American Political Science Review 81: 961-966. 